\title{
ASPEK HUKUM PROSES DIVESTASI SAHAM OLEH PERUSAHAAN PERTAMBANGAN ASING
}

\author{
Melati Adventine Christi Silitonga \\ E-mail: melatisilitonga321@gmail.com \\ Mahasiswa Fakultas Hukum, Universitas Sebelas Maret \\ Adi Sulistiyono \\ E-mail: adi_sumo@yahoo.co.id \\ Dosen Fakultas Hukum, Universitas Sebelas Maret
}

\begin{abstract}
This article aims to examine the legal aspects of the share divestment process carried out by foreign mining companies in Indonesia and related to the obligation of the share divestment process offered to Indonesian Participants by Foreign Mining Companies according to the applicable legislation. This method of writing is legal research with a statute approach. Based on the research, the divestment arrangements in Indonesia still intersect with the non-compliance of foreign mining companies and the uncertainty of regulations in the past, so that the divestment process of foreign mining companies such as PT Freeport Indonesia had problems with the Government. The problem during the divestment of PT Freeport Indonesia's shares due to the incompatibility of permits granted by the Government through the Ministry of Energy and Mineral Resources to PT Freeport Indonesia was feared to provide bad influences for foreign mining companies which would later also divest.
\end{abstract}

Keywords: divestment; share; law; mining

\begin{abstract}
Abstrak
Artikel ini bertujuan untuk mengkaji aspek hukum dari proses divestasi saham yang dilakukan oleh perusahaan pertambangan asing di Indonesia dan terkait dengan kewajiban proses divestasi saham yang ditawarkan kepada Peserta Indonesia oleh Perusahaan Pertambangan Asing menurut perundang-undangan yang berlaku. Metode penulisan ini adalah legal research dengan pendekatan perundang-undangan (statute approach). Berdasarkan penelitian, pengaturan divestasi di Indonesia masih bersinggungan dengan ketidakpatuhan perusahaan pertambangan asing serta ketidaktegasan peraturan di masa lalu sehingga membuat proses divestasi perusahaan pertambangan asing seperti PT Freeport Indonesia sempat bermasalah dengan Pemerintah.. Permasalahan selama divestasi saham PT Freeport Indonesia terbentur pada ketidaksesuaian izin yang diberikan oleh Pemerintah melalui Kementerian Energi dan Sumber Daya Mineral kepada PT Freeport Indonesia dikhawatirkan dapat memberikan influensi yang buruk bagi perusahaanperusahaan pertambangan asing yang nantinya juga akan melakukan divestasi.
\end{abstract}

Kata kunci: divestasi; saham; hukum; pertambangan

\section{A. Pendahuluan}

Membahas perihal divestasi, khususnya divestasi saham dalam pertambangan bukanlah hal baru lagi. Hal itu dibuktikan sejak istilah divestasi saham pertama kali disebutkan pada Pasal 112 angka (1) Undang-Undang Nomor 4 Tahun 2009 tentang Pertambangan Mineral 
dan Batubara, yang menyatakan bahwa setelah 5 (lima) tahun berproduksi, badan usaha pemegang IUP dan IUPK yang sahamnya dimiliki oleh asing wajib melakukan divestasi saham pada Pemerintah, Pemerintah Daerah, Badan Usaha Milik Negara (BUMN), Badan Usaha Milik Daerah (BUMD), dan Badan Usaha Swasta Nasional. Topik mengenai divestasi saham semakin menghangat semenjak publik memperbincangkan sengketa divestasi saham antara pemerintah Indonesia dengan PT. Newmont Nusa Tenggara. (Salim dan Nurbani, 2013: 115)

Divestasi yang dilakukan pemerintah merupakan bentuk upaya strategis pemerintah dalam mempertahankan pembangunan perekonomian bangsa dengan memegang saham dari perusahaan asing terutama di bidang pertambangan, yang berdasarkan pada konstitusi yang mengatur tentang pemanfaatan sumber daya alam. Dalam aturan main dunia bisnis dapat berarti pula sebagai tindakan perusahaan memecah konsentrasi atau pemupukan modal sahamnya sebagai akibat dari larangan terjainya monopolisasi (Iwan Dermawan, 2009 : 2). Dinamika penanaman modal mempengaruhi tinggi rendahnya pertumbuhan ekonomi, mencerminkan tinggi dan lesunya pembangunan (Mutia Sari, 2016: 110). Pasal 33 ayat (1) Undang-Undang Dasar Republik Indonesia Tahun 1945 menyatakan bahwa perekonomian disusun sebagai salah satu usaha bersama berdasarkan asas kekeluargaan, Maka dapat disimpulkan bahwasanya pemanfaatan sumber daya alam ditujukan untuk mencapai kemakmuran rakyat yang sebesar-besarnya. secara garis besar, proses divestasi itu sendiri merupakan proses pelepasan sebuah investasi, di mana pemilik saham lama melepaskan sahamnya. (Ahmad K. Muda, 2003: 117)

Perhatian pemerintah akan divestasi saham pun tidak pernah luput, dibuktikan dari berkembangnya peraturan demi peraturan yang mengemas proses divestasi saham dari berbagai aspek. Karena pada dasarnya divestasi saham merupakan upaya yang dilakukan Pemerintah Indonesia agar perusahaan pertambangan asing mampu membawa manfaat yang lebih besar baik bagi Pemerintah maupun masyarakat Indonesia secara menyeluruh. Namun karena tetap ditemukan masalah-masalah yang menghambat proses divestasi saham oleh perusahaan tambang asing. Penulis ingin mengkaji aspek hukum proses divestasi saham oleh perusahaan tambang asing secara lebih ringkas dan efisien pada jurnal ini.

\section{B. Metode Penelitian}

Jenis penelitian yang digunakan penulis dalam menyususn penelitian ini adalah penelitian hukum normatif, bersifat prespektif, dengan pendekatan yang digunakan adalah pendekatan undang-undang (statute approach). Bahan primer terdiri dari perundang-undangan, catatancatatan resmi atau risalah-risalah dalam pembuatan peraturan perundang-undangan, dan putusan-putusan hakim, bahan hukum sekunder berupa semua publikasi yang bukan merupakan dokumen resmi.

\section{Hasil Penelitian dan Pembahasan}

\section{Aspek Hukum Proses Divestasi Saham Perusahaan Pertambangan Asing}

Adapun pembahasan divestasi yang tersebar dalam peraturan perundang-undangan di Indonesia di antaranya ialah: 
a. Undang-Undang Nomor 1 Tahun 1967 tentang Penanaman Modal Asing Pada Pasal 27 disebutkan bahwa perusahaan asing dengan seluruh modalnya merupakan modal asing, diwajibkan membuka kesempatan partisipasi bagi pemodal nasional secara efektif setelah jangka waktu tertentu dan menurut timbangan yang ditetapkan oleh pemerintah. Hal ini kemudian yang diistilahkan dengan divestasi di mana peserta nasional memiliki kesempatan untuk berpartisipasi pada perusahaan asing. Pasal 10 menyatakan bahwa menteri yang dapat menyelenggarakan urusan pertambangan dapat menunjuk pihak lain sebagai kontraktor jika diperlukan dalam melaksanakan pengusahaan tambang yang dituang dalam perjanjian karya. Dengan demikian, sebagai perusahaan pertambangan asing pertama di Indonesia, PT Freeport resmi membuka anak perusahaan dengan kepemilikan saham sebesar $100 \%$ di Indonesia (Nelsa Nurfitriani dkk, 2016).

b. Undang-Undang Nomor 25 Tahun 2007 tentang Penanaman Modal

Walaupun pada undang-undang ini tidak disebutkan secara jelas mengenai divestasi saham, namun pada Pasal 7 disebutkan mengenai masalah nasionalisasi, di mana Pemerintah tidak akan melakukan tindakan nasionalisasi atau pengambilan hak dan kepemilikan atas penanam modal asing, kecuali terdapat undang-undang yang mengatur. Pada Pasal 8 tertulis bahwa penanam modal dapat mengalihkan aset yang dimilikinya kepada pihak yang diinginkan oleh penanam modal sesuai ketentuan peraturan perundang-undangan.

c. Undang-Undang Nomor 4 Tahun 2009 tentang Pertambangan Mineral dan Batubara Pada Pasal 79 huruf y dituliskan bahwa bagi perusahaan asing pertambangan pemegang IUPK Operasi Produksi memuat divestasi saham sebagai salah satu kewajibannya. Kemudian dalam Pasal 112 diundangkan bahwasanya, setelah 5 (lima) tahun berproduksi, badan usaha pemegang IUP dan IUPK Operasi Produksi yang sahamnya dimiliki oleh asing, wajib melakukan divestasi saham pada Pemerintah,Pemerintah Daerah, Badan Usaha Milik Negara, Badan Usaha Milik Daerah, atau Badan Usaha Swasta Nasional.

d. Peraturan Pemerintah Nomor 20 Tahun 1994 tentang Pemilikin Saham dalam Perusahaan yang Didirikan dalam Rangka Penanaman Modal Asing

Pada Pasal 7 disebutkan bahwa perusahaan asing yang didirikan dalam jangka waktu 15 (lima belas) tahun sejak berproduksi harus menjual sebagian sahamnya kepada warga negara Indonesia dan/atau badan usaha hukum Indonesia melalui pemilikan langsung atau melalui pasar modal. Menurut hemat penulis, pasal ini mengatur mengenai kewajiban divestasi saham khususnya saham yang dimiliki oleh investor asing, dengan kisaran jumlah saham yang harus didivestasi sebesar 50\%.

e. Peraturan Pemerintah Nomor 1 Tahun 2008 tentang Investasi Pemerintah Dalam peraturan pemerintah ini, divestasi diartikan sebagai penjualan surat dan/atau kepemilikan pemerintah baik sebagian atau keseluruh kepada pihak lain. Dalam hal ini, divestasi tersebut dilakukan oleh pemerintah kepada pihak lain yang merupakan warga negara Indonesia.

f. Peraturan Pemerintah Nomor 1 Tahun 2017 tentang Perubahan Keempat Atas Peraturan Pemerintah Nomor 23 Tahun 2010 tentang Pelaksanaan Kegiatan Usaha Pertambangan Mineral dan Batubara 
Pada Pasal 97 ditentukan bahwa pemodal asing pemegang IUP dan IUPK setelah 5 (lima) tahun berproduksi, wajib melakukan divestasi saham secara bertahap sehingga pada tahun kesepuluh paling sedikit 51\% sahamnya dimiliki oleh peserta Indonesia. Setelah tahun kelima sejak produksi, saham pemodal asing ini harus dimiliki peserta Indonesia tidak boleh kurang dari persetasi sebagai berikut:

1) tahun keenam $20 \%$ (dua puluh persen)

2) tahun ketujuh $30 \%$ (tiga puluh persen)

3) tahun kedelapan 37\% (tiga puluh tujuh persen)

4) tahun kesembilan $44 \%$ (empat puluh empat persen); dan

5) tahun kesepuluh 51\% (lima puluh satu persen), dari jumlah seluruh saham.

Proses divestasi saham dapat dilakukan kepada peserta Indonesia yang terdiri atas Pemerintah, Pemerintah Daerah Provinsi atau Pemerintah Daerah Kabupaten/Kota, BUMN, BUMD, atau Badan Usaha Swasta Nasional. Ketika Pemeintah tidak bersedia membeli saham makan akan ditawarkan kepada Pemerintah Daeah Provinsi atau Pemerintah Daerah Kabupaten/Kota. Pun ketika Pemerintah Daeah Provinsi atau Pemerintah Daerah Kabupaten/Kota tidak bersedia maka ditawarkan kepada BUMN dan BUMD, dan bila BUMD dan BUMD tidak bersedia makan penawaran saham akan ditawarkan kepada badan usaha swasta nasional.

g. Peraturan Menteri Energi dan Sumber Daya Mineral Republik Indonesia Nomor 09 Tahun 2017 jo Peraturan Menteri Energi dan Sumber Daya Mineral Republik Indonesia Nomor 43 Tahun 2018 tentang Tata Cara Divestasi Saham dan Mekanisme Penetapan Harga Saham Divestasi Pada Kegiatan Usaha Pertambangan Mineral dan Batubara

Aturan paling baru yang dikeluarkan oleh Menteri Energi dan Sumber Daya Mineral ini diharapkan dapat melengkapi perangkat peraturan yang mengatur khusus mengenai kegiatan divestasi, mengingat Peraturan Menteri Energi dan Sumber Daya Mineral Republik Indonesia Nomor 09 Tahun 2017 jo Peraturan Menteri Energi dan Sumber Daya Mineral Republik Indonesia Nomor 43 Tahun 2018 tentang Tata Cara Divestasi Saham dan Mekanisme Penetapan Harga Saham Divestasi Pada Kegiatan Usaha Pertambangan Mineral dan Batubara tidak hanya mengatur divestasi, tetapi juga mengenai perubahan penanaman modal di bidang usaha pertambang mineral dan batubara.

Dibandingkan dengan negara lain, Indonesia masih belum memiliki undang-undang yang mengatur tentang divestasi. Salah satu negara yang telah mengatur perundangundangan tentang divestasi adalah Sudan. Sebagai negara penghasil emas terbesar di Afrika di tahun 2014 (Mowafa Taib, 2017: 41.1) Sudan telah memiliki Sudan Accountability and Divestment Act of 2007 (S.2271 - 110 ${ }^{\text {th }}$ Congress Government, https://www.congress.gov/bill/110th-congress/senate-bill/2271 di akses pada 28 Maret 2019)

Pada Bagian 3 Kewenangan Negara dan Pemerintah Daerah Untuk Divestasi dari Perusahaan Tertentu dengan Investasi langsung di Sektor Tertentu Masyarakat Sudan huruf d angka (1) Sudan Accountability and Divestment Act of 2007 terdapat empat jenis kegiatan bisnis yang dapat didivestasikan, yakni produksi tenaga listrik (power production activities), pertambangan mineral (mineral extraction activities), perminyakan 
(oil-related activities), dan produksi perlengkapan militer (the production of military equipment).

Pada Bagian 4 Perlindungan Aman Untuk Perubahan Kebijakan Investasi huruf b menyatakan, bahwa selambat-lambatnya 120 hari setelah berlakunya Sudan Accountability and Divestment Act of 2007 Komisi Sekuritas dan Bursa harus menetapkan aturan untuk kepentingan umum dan untuk perlindungan investor agar mendaftarkan masing-masing perusahaan pada saat mendivestasikan diri pada efek.

Terdapat perbedaan dalam pelaksanaan divestasi saham yang dilakukan oleh Pemerintah Indonesia dengan Pemerintah Sudan. Jika Pemerintah Indonesia melaksanakan divestasi melalui beberapa jenjang yang didelegasikan terlebih dahulu pada Menteri. Di Sudan, pelaksanaan divestasi saham dilakukan oleh Komisis Sekuritas atau Bursa Saham. Sedangkan perusahaan pertambangan asing di Indonesia baru bisa melepaskan saham divestasinya di IPO jika penawaran divestasi yang dilakukannya tidak disanggupi dan sudah ditawarkan secara berjenjang.

\section{Permasalahan Divestasi Saham di Indonesia dan Penyelesaiannya.}

Pada akhir tahun 2018 lalu, Kementerian Energi dan Sumber Daya Mineral melalui Subsektor Minerba terjadi pencapaian dengan beralihnya 51,23\% saham mayoritas PT. Freeport Indonesia (PT. FI) kepada PT. Indonesia Asahan Aluminium (PT. Inalum). Resminya pengalihan saham tersebut ditandai dengan proses pembayaran dan terbitnya Izin Usaha Pertambangan Khusus Operasi Produksi (IUPK-OP) sebagai pengganti Kontrak Karya PT. FI yang telah berjalan sejak tahun 1967 dan diperbaharui di tahun 1991 dengan masa berlaku hingga 2021. Kepemilikan 51,23\% saham tersebut nantinya akan terdiri dari 41,23\% untuk PT. Inalum dan 10\% untuk Pemerintah Daerah Papua. Dari 10\% saham PT. FI yang dipegang Pemerintah Daerah Papua nantinya akan dikelola oleh perusahaan khusus PT Indonesia Papua Metal dan Mineral yang 60\% sahamnya akan dimiliki oleh PT. Inalum dan 40\% oleh BUMD Papua. (Siaran Pers Bersama, Kementerian Energi dan Sumber Daya Mineral, Nomor: 0035.Pers/04/SJI/2009 Tahun 2019)

Namun tidak dipungkiri bahwa selama proses divestasi saham oleh perusahaan pertambangan asing berlangsung, terdapat problematika yang membayangi. Salah satu problematika yang dihadapi peserta Indonesia dalam membeli divestasi saham PT. FI yakni penerbitan IUPK-OP. Sebagaimana dijelaskan dalam Ketentuan Peralihan dalam Pasal 169 huruf (a) dan huruf (b) Undang-Undang Nomor 4 Tahun 2019 tentang Pertambangan Mineral dan Batubara, mengatur ketentuan pemberlakuan undang-undang di mana Kontrak Karya dan perjanjian karya pengusahaan pertambangan batubara yang telah ada sebelum berlakunya Undang-Undang ini tetap diberlakukan sampai jangka waktu berakhirnya kontrak/perjanjian, sehingga ketentuan yang terdapat dalam kontrak karya dan perjanjian karya pengusahaan pertambangan harus disesuai selambat-lambatnya 1 (satu) tahun sejak diberlakukannnya Undang-Undang ini. Kembali ditegaskan dalam Pasal 3 Peraturan Menteri ESDM Nomor 34 Tahun 2017 tentang Perijinan di Bidang Pertambangan Mineral dan Batubara, bahwa badan usaha, koperasi, dan perseorangan hanya dapat melaksanakan kegiatan usaha pertambangan mineral dan batubara setelah mendapatkan izin usaha di bidang pertambangan mineral dan batubara. 
Sebelum PT. Inalum berhasil membeli 41,6\% saham divestasi PT. FI dengan senilai US $\$ 3,85$ miliar, terdapat beberapa problematika yang dihadapi Pemerintah. Direktur Jenderal Mineral dan Batubara Kementerian Energi dan Sumber Daya Mineral, Bambang Gatot Ariyono, mengatakan IUPK Sementara harus diperpanjang karena divestasi oleh PT. Inalum belum juga rampung. (CNN Indonesia, https://www.cnnindonesia. com/ekonomi/20181121155508-85-348149/pemerintah-akui-terpaksa-terbitkan-iupksementara-freeport, diakses pada 6 April 2019 pukul 13.59 WIB) Penerbitan IUPK Sementara oleh Menteri ESDM terhadap PT. FI terbilang menyalahi perundang-undangan yang berlaku. Di mana, PT. FI selaku pihak yang mengantungi IUPK Sementara memperoleh izin untuk melakukan ekspor ke luar berupa ekspor konsentrat tembaga. Hal ini menimbulkan persepsi bahwa dengan memberikan IUPK Sementara kepada PT. FI dapat mencederai implementasi dari Undang-Undang Nomor 4 Tahun 2009.

Ketika sebuah perusahaan pertambangan yang sahamnya dimiliki oleh pihak asing sudah mendapatkan IUPK sebagai legitimasi dalam melakukan usaha pertambangan, sudah sepatutnya melakukan proses kewilayahan pengusahaan pertambangan melalui penawaran terlebih dahulu terhadap Wilayah Izin Usaha Pertambangan Khusus (selanjutnya disebut WIUPK), hingga memperoleh Izin Usaha Pertambangan Khusus Eksplorasi (selanjutnya disebut IUPK Eksplorasi). Menteri Energi dan Sumber Daya Mineral menawarkan WIUPK, kepada BUMN dan BUMD dengan cara memprioritaskan asal dan tempat WIUPK tersebut berada. Jika BUMN atau BUMD berminat lebih dari satu, dan/atau tidak ada yang berminat, maka WIUPK tersebut akan ditawarkan kepada badan usaha swasta dengan cara lelang. Dalam pelaksanaan lelang WIUPK, perusahaan pertambangan yang hendak menawar WIUPK harus menjadi peserta lelang yang melewati tahap prakualifikasi dan kualifikasi, setelah dinyatakan memenangkan lelang atas WIUPK, kemudian perusahaan pertambangan tersebut wajib mengajukan permohonan IUPK Eksplorasi paling lambat 5 hari kerja sejak pembayaran biaya kompensasi data informasi. Pengajuan permohonan IUPK Eksplorasi diajukan kepada Menteri oleh perusahaan pertambangan terkait untuk melakukan tahapan kegiatan penyelidikan umum, eksplorasi, dan studi kelayakan WIUPK. Setelah jangka waktu eksplorasi selesai, perusahaan pertambangan pemegang IUPK Eksplorasi harus sudah melakukan penyelidikan umum, eksplorasi dan studi kelayakan sehingga dapat mengajukan permohonan IUPK Operasi Produksi kepada Menteri Energi dan Sumber Daya Mineral.

Inilah bentuk ketidakkonsistenan kedua pihak yang menunjukkan adanya dua rezim hukum yang berbeda yakni kontrak dan izin atas kegiatan pertambangan yang ada pada saat bersamaan. Sebagai jalan tengah Pemerintah melalui Kementerian Energi dan Sumber Daya Mineral pun menerbitkan IUPK Sementara dan izin ekspor konsentrat bagi PT. FI untuk tetap melakukan produksi. PT. FI sebagai pemegang IUPK Sementara tidak memiliki fasilitas pengolahan dan pemurnian, hal ini yang juga menjadi salah satu alasan pengajuan izin ekspor konsentrat oleh PT. FI sehingga perusahaan tersebut tetap dapat melakukan ekspor tanpa harus melakukan pemurnian terlebih dahulu. Padahal PT. FI dapat mengolah dan memurnikan hasil penambangannya dari pemegang IUP dan IUPK Operasi Produksi lainnya sepanjang pemegang IUP dan IUPK Operasi Produksi lainnya memiliki fasilitas pengolahan dan pemurnian guna meningkatkan nilai tambah 
dari penambangan. Perlu digaris bawahi bahwa, setiap perusahaan pertambangan asing yang hendak melakukan usaha penambangan di Indonesia harus mengikuti prosedur yang berlaku sesuai dengan peraturan perundang-undangan, dimulai dari penawaran WIUP/ WIUPK, memohon IUP/IUPK Eksplorasi, lalu mengantungi IUPK Operasi Produksi, dan kemudian melaksanakan divestasi saham kepada peserta Indonesia. Karena hal ini menjadi salah satu faktor penentu kelancaran dalam proses divestasi. Rentang proses penawaran WIUP/WIUPK, memohon IUP/IUPK Eksplorasi, lalu mengantungi IUPK Operasi Produksi, juga memiliki faktor pengaruh terkait penetapan harga saham divestasi. Semakin lama rentang waktu negosiasi penentu harga saham divestasi PT FREEPORT INDONESIA dengan PT INDONESIA ASAHAM ALUMINIUM, semakin lama pula penerbitan IUPK Operasi Produksi PT FREEPORT INDONESIA oleh Menteri Energi dan Sumber Daya Mineral sehingga PT FREEPORT INDONESIA yang memegang IUPK Sementara masih tetap dapat melakukan ekspor konsentrat, yang tentu saja menyalahi aturan dari Undang-Undang Nomor 4 Tahun 2009 tentang Pertambangan Mineral dan Batubara.

Hal ini berkaitan dengan proses divestasi saham selanjutnya yang hendak dilaksanakan di Indonesia. Jangan sampai, perusahaan pertambangan asing selanjutnya mengikuti kedua perusahaan besar ini dan menginfluensikan pengaruh buruk terhadap proses divestasi

\section{Simpulan}

1. Aspek hukum divestasi dalam peraturan perundang-undangan di Indonesia di antaranya ialah Undang-Undang Nomor 1 Tahun 1967 tentang Penanaman Modal Asing yang kini digantikan Undang-Undang Nomor 25 Tahun 2007 tentang Penanaman Modal, Pasal 112 Undang-Undang Nomor 4 Tahun 2009 tentang Pertambangan Mineral dan Batubara, Pasal 7 Peraturan Pemerintah Nomor 20 Tahun 1994 tentang Pemilikan Saham dalam Perusahaan yang Didirikan dalam Rangka Penanaman Modal Asing, Peraturan Pemerintah Nomor 1 Tahun 2008 tentang Investasi Pemerintah, Peraturan Nomor 1 Tahun 2017 tentang Perubahan Keempat Atas Peraturan Pemerintah Nomor 23 Tahun 2010 tentang Pelaksanaan Kegiatan Usaha Pertambangan Mineral dan Batubara, dan Peraturan Menteri Energi dan Sumber Daya Mineral Republik Indonesia Nomor 09 Tahun 2017 jo Peraturan Menteri Energi dan Sumber Daya Mineral Republik Indonesia Nomor 43 Tahun 2018 tentang Tata Cara Divestasi Saham dan Mekanisme Penetapan Harga Saham Divestasi Pada Kegiatan Usaha Pertambangan Mineral dan Batubara

2. Problematika proses divestasi saham PT. FI yang dalam proses negosiasi harga saham 41,6\% tersebut membuat Menteri Energi dan Sumber Daya Mineral menerbitkan IUPK Sementara di mana PT. FI masih dapat melakukan ekspor ke luar negeri tanpa melakukan pemurnian melainkan berupa konsentrat tembaga. IUPK Sementara yang dikeluarkan Kementerian Energi dan Sumber Daya Mineral tidak diatur dalam Undang-Undang Nomor 4 Tahun 2009 tentang Pertambangan Mineral dan Batubara. Hal ini menyalahi peraturan terkait proses pemberian IUP/IUPK Operasi Produksi yang diatur dalam peraturan perundangan di mana perusahaan harus melakukan pengusahaan wilayah pertambangan terlebih dahulu. 


\section{E. Saran}

1. Dalam meninjau aspek hukum proses divestasi saham, perlu diusulkan kepada dan/atau oleh DPR dengan menekankan secara rinci makna mendasar divestasi dan divestasi saham untuk membuat Undan-Undang tentang Divestasi. Barulah tata cara divestasi saham dapat diatur lebih mendalam pada peraturan pemerintah/peraturan menteri. Seperti yang sudah ada pada Peraturan Menteri Nomor 09 Tahun 2018 tentang Tata Cara Divestasi Saham dan Mekanisme Penetapan Harga Saham Divestasi Pada Kegiatan Usaha Pertambangan Mineral dan Batubara.

2. Dalam menyelesaikan sengketa dan problematika dalam divestasi saham, Pemerintah harus mengedepankan konsistensi atas penyelenggaraan hukum yang ada. Di mana, tiap peraturan yang telah disahkan dijadikan pegangan serta pedoman baik oleh perusahaan pertambangan asing yang hendak melakukan proses divestasi saham, sedang melakukan proses divestasi, hingga yang telah melakukan divestasi untuk tetap mengikuti tata laksana.

\section{F. Daftar Pusataka}

Salim HS dan Erlies Septianan Nurbani. 2013. Hukum Divestasi di Indonesia (Pasca Putusan Mahkamah Konstitusi RI Nomor 2/SKLN.X/2012). Jakarta: Rajawali Pers.

Aminuddin Ilmar. 2004. Hukum Penanaman Modal di Indonesia. Jakarta: Kencana.

Ahmad K. Muda. 2003. Kamus Lengkap Ekonomi. Jakarta: Gita Media.

Iwan Dermawan. 2009. "Kewajiban Divestaasi Saham Pada Penanaman Modal Asing Bidang Pertambangan Umum (Studi kasus pada Perjanjian Kontrak Karya antara PT NTT dengan Pemerintah Indonesia)”. Disertasi. Depok: Fakultas Hukum Universitsa Indonesia

Mowafa Taib. 2017. "The Mineral Industry of Sudan”. Minerals Yearbook. Volume III. Amerika Serikat: USGS Science for A Changing World

Mutia Sari. 2016. "Pengaruh Investasi, Tenaga Kerja dan Pengeluaran Pemerintah terhadap Pertumbuhan Ekonomi di Indonesia". Jurnal Ekonomi dan Kebijakan Publik. Volume 3 Nomor 2. Aceh: Universitas Syiah Kuala.

Nelsa Nurfitriani Pratama 2016. "Pengaturan Kewajiban Divestasi Saham dalam Perusahaan Modal Asing di Bidang Pertambangan Menurut PP. No 77 Tahun 2014 tentang Pelaksanaan Kegiatan Usaha Pertambangan Mineral dan Batubara". Diponegoro Law Review. Volume 5 Nomor 2. Semarang: Fakultas Hukum Universitas Diponegoro

Siaran Pers Bersama, Kementerian Energi dan Sumber Daya Mineral, Nomor: 0035.Pers/04/ SJI/2009 Tahun 2019

S.2271 - $110^{\text {th }}$ Congress Government, https://www.congress.gov/bill/110th-congress/senatebill/2271

CNN Indonesia, https://www.cnnindonesia.com/ekonomi/20181121155508-85-348149/ pemerintah-akui-terpaksa-terbitkan-iupk-sementara-freeport 